\title{
POLITIKK
}

SKANDINAVISK TIDSSKRIFT

FOR INTERNASJONALE STUDIER

Årgang 80, Nummer 1, side 6-27, 2022, ISSN 1891-1757, www.tidsskriftet-ip.no, Publisert januar 2022

\section{Grænser for handlefrihed: Skandinaviske stater i asymmetrisk bilateralt diplomati}

\author{
Hans Mouritzen \\ Dansk Institut for Internationale Studier (DIIS), Danmark
}

\begin{abstract}
Sammenfatning
Bilateralt diplomati er ikke en skandinavisk spidskompetence, men det har fået stigende betydning i dagens verden. Et antal cases analyseres her, i hvilke de skandinaviske lande er blevet bilateralt 'disciplineret' af stormagter som Rusland, Kina, Indien eller USA. Sammenlignet med de første ca. 15 år efter Den Kolde Krig med amerikansk hegemoni og EU's normative magt har de nordiske lande måttet erfare en indsnævring af deres handlefrihed. Det er ikke længere muligt, uden betydelige omkostninger, at kritisere stormagter baseret på universelle værdier. Generelt er det selvsagt vigtigt for beslutningstagere at respektere statens eksterne handlefrihed. Men på den anden side må de ikke være overforsigtige og undlade at prøve grænser af, bl.a. af hensyn til den hjemlige arena. 'Bastioner' må etableres og forsvares med troværdighed. Handlefrihedens grænser er svære at identificere, men prøveballoner, paralleladfærd med beslægtede lande eller måske brug af 'historiens lære' kan være gangbare metoder.
\end{abstract}

Nøgleord: handlerum • småstater • asymmetriske relationer • bastioner

Det er fristende for enhver stat at forsøge at 'eksportere' sit hjemlige værdisystem til hele verden, herunder kritisere udvalgte stater for ikke at leve op til det. Den udenrigspolitiske handlefrihed til at gøre det varierer dog kraftigt. De skandinaviske

\footnotetext{
^Kontaktinformasjon: Hans Mouritzen, e-post: hmo@diis.dk

(C2022 Hans Mouritzen. This is an Open Access article distributed under the terms of the Creative Commons Attribution 4.0 International License (https://creativecommons.org/licenses/BY/4.0/), allowing third parties to copy and redistribute the material in any medium or format and to remix, transform, and build upon the material for any purpose, even commercially, provided the original work is properly cited and states its license.

Citation: Mouritzen, H. (2022). Grenser for handlefrihed: Skandinaviske stater $i$ asymmetrisk bilateralt diplomati. Internasjonal Politikk, 80(1), 6-27. http://dx.doi.org/10.23865/intpol.v80.3078
} 
lande, som i kraft af rodfæstede demokratiske systemer er overbeviste om egne værdiers universalitet, har oplevet både gode og dårlige konjunkturer for værdieksport. Konjunkturerne indvirker selvsagt på udenrigspolitisk indflydelse generelt, men værdipolitikken er det mest følsomme barometer.

Denne artikel undersøger en række situationer inden for de sidste 20 år, hvor grænserne for skandinaviske landes (eksterne) handlefrihed har vist sig tydeligere end normalt. I praksis drejer det sig om bilaterale konflikter med stormagter, typisk af værdipolitisk art. Disse situationer er velegnede til at belyse beslutningstagernes dilemmaer og metoder til at vurdere landets handlefrihed. Selvom handlefrihedens grænser i praksis kan være vanskeligt identificerbare, argumenterer artiklen for, at et begreb om objektiv handlefrihed er meningsfuldt og kan gøre gavn analytisk. Det tilfører et kritisk potentiale i forhold til den førte politik.

Handlefrihedens glansdage for bl.a. de skandinaviske lande var USAunipolariteten i 1990'erne og første halvdel af 2000'erne, yderligere fremmet af EU som selvudråbt 'normativ magt' i samme periode. Det (relative) værdifællesskab med den amerikanske hegemon var en god platform. ${ }^{1}$ Samtidig kunne EU og NATO 'opdrage' deres mange europæiske ansøgerlande til deres eget værdisystem som en konditionalitet for medlemskab. Modtagere af bistandshjælp i den tredje verden var ret ensidigt afhængige af vestlig bistand og kunne derfor også underkastes konditionalitet. Endvidere var perioden præget af rimeligt fungerende multilateralt diplomati, både i og uden for FN. Multilateralt diplomati er en fordel for små og mellemstore magter, som kan bedrive afhængighedsspredning inden for rammerne af de internationale organisationer: De behøver ikke bringe sig i et ensidigt afhængighedsforhold til én bestemt stormagt.

Efterhånden har bilateralt diplomati imidlertid fået stigende betydning på bekostning af det multilaterale; ikke mindst Trump-administrationen foretrak åbenlyst bilaterale (eller unilaterale) løsninger. Multipolariteten i international politik allerede fra slutningen af 2000'erne ${ }^{2}$ medførte en betydelig uforudsigelighed i bilaterale relationer. En værdibaseret profil var tilsyneladende stadig attraktiv for mange små og mellemstore lande som de skandinaviske, i nogle tilfælde for at teste, om deres handlefrihed var intakt. Men disciplinerende reaktioner var lige så tillokkende for nye stormagter, der ønskede at demonstrere deres nyvundne magt og status (Larson \& Shevchenko, 2014). Dette efterlod ved flere lejligheder den mindre stat i en asymmetrisk bilateral relation med ringe solidaritet fra venner eller allierede.

\footnotetext{
${ }^{1}$ Selvom der dog også var splittelser. Den europæiske Irak-konflikt stod mellem tilhængere og modstandere af USA's angreb på Irak, som savnede et klart FN-mandat.

${ }^{2}$ Ifølge Waltz's (1979) definition af polaritet baseret på besiddelse af militære og økonomiske magtkapabiliteter er verden stadig unipolær (så sent som 2020 spenderede USA lige så meget som de 12 følgende stater tilsammen på listen over militærudgifter, om end Kina er nået op på ca. en tredjedel af USA; jf. SIPRI 2020). Her er kriteriet imidlertid evnen til at projicere magt (Boulding, 1962) med skabelse af indflydelsessfærer omkring sig. Fra slut-2000'erne havde også Kina og Rusland markante indflydelsessfærer. Geografisk nærhed har fået stigende betydning (Mouritzen, 2017).
} 
Navnlig i Trump-perioden var USA en stormagt som de øvrige, uden værdipolitisk profil (og tillige mere volatil).

Der er adskillige situationer, hvor skandinaverne er blevet udsat for (forsøg på) disciplinering fra en stormagt: Danmark 2002-09, Sverige fra 2008 og Norge fra 2015 af Rusland; Danmark 2009, Norge 2010-18 og Sverige fra 2018 af Kina; og Danmark 2010-18 af Indien. De fleste af tilfældene handler om nordisk universalisme overfor BRIC-landes ${ }^{3}$ nyvundne prestige. Hertil kan føjes amerikansk disciplinering af svensk kernevåbendiplomati 2017-19 og en kortvarig dansk-amerikansk krise i efteråret 2019. Fællesnævneren for situationerne er, at det nordiske land - set i bakspejlet - er kommet til at overskride sin handlefrihed. Ingen af de nordiske lande så den resulterende bilaterale krise som ønskværdig, tværtimod. Som 'straf' blev de bilaterale kontakter frosset ned, ofte i en længere periode. Bortset måske fra et enkelt tilfælde var der dog ingen af skandinaverne, der lod sig ydmyge. Men skønt de har været dygtige til at kamuflere disciplineringerne, er det sikkert, at erfaringerne vil have langtidsvirkninger for deres profil i de pågældende bilaterale relationer.

Konfliktsituationer med tilhørende disciplineringer er velegnede til at belyse handlefrihedens grænser (af formen 'hertil og ikke længere'). Grænserne for skandinavisk handlefrihed var i udgangspunktet utydelige, men krisen og den medfølgende stormagtsdisciplinering illuminerede handlefrihedens grænser. Dette fokus giver ikke noget generelt billede af små eller mellemstore magters vilkår; sigtet her er ikke at forklejne de nordiske landes mange udenrigspolitiske succeser, bl.a. som "norm entrepreneurs" (Ingebritsen, 2002; Björkdahl, 2007). Men disse er karakteristisk nok oftest at finde i multilaterale fora i multilateralismens glansdage, jf. det nedarvede nordiske renommé i FN helt tilbage fra Den Kolde Krig, Danmarks og Sveriges bidrag til EU-udvidelserne i slut-1990'erne eller Danmarks bidrag til de baltiske NATO-medlemskaber i samme periode (det skal dog erkendes, at Norges aftale med Rusland om en grænsedragning i Barentshavet 2010 ifølge sagens natur var en bilateral succeshistorie efter 40 års frossen uenighed). Udsat for disciplinering handler det ikke om offensive indflydelsesstrategier, men snarere om 'back to basics' og delikate balancer. Det er sandt nok, at de skandinaviske lande bruger forskellige indflydelsesstrategier i kraft af at have udviklet forskellige repertoirer (Haugevik \& Sending 2020), men kommer de under bilateralt pres, er reaktionerne forbløffende ens. Det handler ikke om at vinde ny status, men at bevare og evt. udnytte ${ }^{4}$ den status, man har fra tidligere.

I det følgende kommer først en begrebsafklaring. Herefter følger redegørelser for de kriser, som hver især bidrog til at operationalisere handlefrihedens grænser i de konkrete situationer. For hver krise spørges: Hvori bestod skandinavernes overtrædelse

\footnotetext{
${ }^{3}$ BRIC-landene omfatter Brasilien, Rusland, Indien og Kina, som med imponerende vækstrater i starten af det 21. århundrede blev set som poler i en kommende verdenspolitisk multipolaritet.

${ }^{4}$ Historisk har Danmark og Finland udnyttet deres status som 'nordisk land' i perioder, hvor de har været presset af hhv. deres sydlige eller østlige stormagtsnabo.
} 
af deres handlefrihed? Hvad blev 'straffen'? Hvordan - om overhovedet - er det lykkedes at løse den bilaterale krise? Herefter ser vi på, hvordan beslutningstagere generelt kan manøvrere i bilateralt diplomati ved forsvar af såkaldte 'bastioner', herunder identificere grænserne for statens eksterne handlefrihed. Hvordan spiller sidstnævnte sammen med den hjemlige arena?

\section{Handlefrihed som analytisk begreb}

Begrebet 'handlefrihed' (manøvrerum, handlerum) bruges i daglig tale af beslutningstagere, diplomater, kommentatorer ${ }^{5}$ og ikke mindst historikere. F.eks. af formen: "Tilsit-aftalen mellem kejser Napoleon og zar Alexander indskrænkede den svenske udenrigspolitiske handlefrihed." Her handler det ikke om, at beslutningstagerne i Stockholm nødvendigvis indså dette (deres perception), men om Sveriges objektive handlefrihed (i beslutningstagernes operationelle miljø, Sprout \& Sprout, 1957, s. 318).

Ikke desto mindre indtager begrebet ekstern handlefrihed ${ }^{6}$ en meget beskeden plads i 'international politiks' (IP's) teoriansatser. Dets brug er bl.a. blevet hæmmet af to vidt forskellige opfattelser af udenrigspolitik. På den ene side voluntaristiske opfattelser, ifølge hvilke stater er fri til at vælge deres egen skæbne, ganske vist i interaktion med andre, men uden nævneværdig hensyn til stabile emne-hierarkier eller en evt. magtunderlegenhed (-asymmetri). Objektiv handlefrihed findes ikke i et sådant perspektiv. På den anden side, mere overraskende, har neorealister ignoreret begrebet, formentlig på grund af stormagtsbias. Eftersom handlefrihed generelt ikke er et knapt gode for en supermagt eller stormagt, bliver fænomenet og begrebet mindre notabelt for deres analytikere. Inspireret af Waltz' (1979) dikotomiske skel mellem "systemic structure" og "domestic politics", som accepteredes langt ud over realismens grænser, oversås staternes ncere omgivelser, som jo typisk er arnestedet for de mest snærende bånd i forhold til ikke-stormagters handlefrihed. Dette er utilfredsstillende, hvis man sigter mod opstilling af generelt gyldige antagelser om udenrigspolitik. De færreste stater er stormagter.

Den dominerende voluntaristiske retning, konstruktivismen, påstod i sin polemik mod realismen, at international politiks anarki - men i virkeligheden også dens struktur - er "what states make of it" (Wendt, 1992, 1999; Fiammenghi, 2019). Det er en gyldig kritik af Waltz (1979), at proces ofte er vigtigere end struktur, især en

\footnotetext{
${ }^{5}$ Engelske synonymer er f.eks. 'autonomy', 'margin of manoeuvre' eller 'room for manoeuvre'. På tysk 'Handlungsfreiheit' eller 'Spielraum', på fransk 'liberté d'action' eller 'marge de manoeuvre'. Se i øvrigt nogle begrebslige overvejelser hos Dunér (1979). Bekkevold (2021) bruger ordet 'handlerom' flere steder uden at gå ind i en begrebslig analyse.

${ }^{6}$ Interessen gælder her ekstern handlefrihed. Ifølge en realistisk IP-opfattelse har ekstern handlefrihed primat over intern handlefrihed (regeringens handlefrihed på hjemmefronten). Interaktionen mellem ekstern og intern handlefrihed vil blive behandlet i afsnittet "Samspil med den hjemlige handlefrihed".
} 
overordnet systemisk struktur. Men argumentet drives for vidt. Wendt deler Waltz' negligering af det spatiale aspekt og mister derved blikket for de knap så magtfuldes position, især dem beliggende $\mathrm{i}$ andres indflydelsessfære eller klemt mellem stormagter (Handel, 2006, s. 190-191). For dem er handlefrihed $i k k e$, hvad de gør den til; ${ }^{7}$ der er grænser sat af andre. De føler det akut, fordi handlefriheden er et knapt gode. Den kan udvides i et længere tidsperspektiv, undertiden som et resultat af statens egne anstrengelser (typisk ved at styrke multilateralt diplomati eller småstatssammenhold generelt). ${ }^{8}$ Men handlefriheden er en parameter på kort sigt; staten må tilpasse sin strategi og adfærd derefter. Modsat har f.eks. den amerikanske supermagt, selv under dalende global indflydelse, langt mere overskud til at lege indenrigspolitik eller at følge personlige præsidentielle nøkker på verdensscenen.

Den spredte eksplicitte litteratur om handlefrihed findes i adaptationsstudier (Petersen, 1979, Mouritzen, 1988) og i diskussioner af forholdet mellem ekstern og hjemlig handlefrihed (Hanrieder, 1967; Putnam, 1988; Moravscik, 1999; Mariager \& Wivel, 2019), som vil blive uddybet i det relevante afsnit herom. ${ }^{9}$

Ekstern handlefrihed i udenrigspolitik defineres her som de politikmuligheder, som tillades af den omgivende magtstruktur $i$ en given situation (se figur 1). For at begrebet skal være meningsfuldt, må der foreligge et tydeligt hierarki af emner. For det vigtigste af disse må der foreligge en betragtelig risiko for et 'uacceptabelt udfald'; det må simpelt hen ikke indtræffe. En passager i en lufthavn i venten på sit fly kan udrette forskellige ærinder som at handle toldfrit, købe en sandwich eller lignende. Men ét hensyn er vigtigere: at holde tjek på 'boarding time' og gåafstanden til gate. Han ved, at piloten ikke venter; man forhandler ikke om afgangstiden. At nå flyet er m.a.o. aksiomatisk i situationen, mens de nævnte ærinder i sammenligning er en luksus. Skulle flyet blive forsinket, får passageren pludselig tid til ekstra ærinder, men sagen er, at dette er uden for hans kontrol. Flyafgang er m.a.o. en parameter, der begrænser hans handlefrihed.

Også for stater er visse udfald uacceptable $\mathrm{i}$ en given situation. Kun i sjældne tilfælde har vi at gøre med absolutte katastrofer som statsopløsning, territorialtab eller økonomiske/epidemiske katastrofer. Men det uacceptable udfald er markant værre end andre relevante udfald (jf. emnehierarkiet). F.eks. må en politisk aktør

\footnotetext{
${ }^{7}$ Det kan måske undre, at konstruktivismen her klassificeres som 'voluntaristisk', eftersom staten jo i denne tankegang i nogen grad er begrænset af sin egen tidligere diskurs. Men diskurs er som oftest en meget vag begrænsning i forhold til konkret adfærd. Desuden står den selvvalgt i modsætning til realismens eller neoliberalismens mere håndfaste begrænsninger.

${ }^{8}$ I et IP-realistisk perspektiv (som her) er der dog en øvre grænse for virkningerne af disse anstrengelser. På lang sigt er oprustning en mulighed, og staten kan selv træffe andre forberedende foranstaltninger for at forøge antallet af 'knapper' at trykke på i en krisesituation.

${ }^{9}$ Den såkaldte neoklassiske realisme bruger betegnelsen "nature of strategic environment (permissive to restrictive)", hvilket synes at svare til ekstern handlefrihed her (se Ripsman, Taliaferro \& Lobell, 2016, s. 52-56 og 94-95).
} 
ikke miste sin basale troværdighed, fordi det kan tage mange år at genetablere den; det er derfor, politikeres hensigtserklæringer typisk er så vage, som de er.

Snarere end positivt at følge en vision, der angiver en bestemt vej frem - som i veltalende diskurs - søger stater at undgå nærmerede specificerede dårligdomme. Disse fungerer som advarselsskilte, der 'overruler' andre hensyn eller overvejelser. Det skal dog i denne forbindelse huskes, selvsagt, at 'dårlige ting' kan ske af mange andre grunde, end at staten selv overskrider sin handlefrihed (banale uheld, f.eks.).

Handlefriheden har imidlertid meget utydelige grænser (se gråzonerne i figur 1). Handlefrihed forudsætter begrebet "anticiperet reaktion" ("anticipated reaction"): ${ }^{10}$

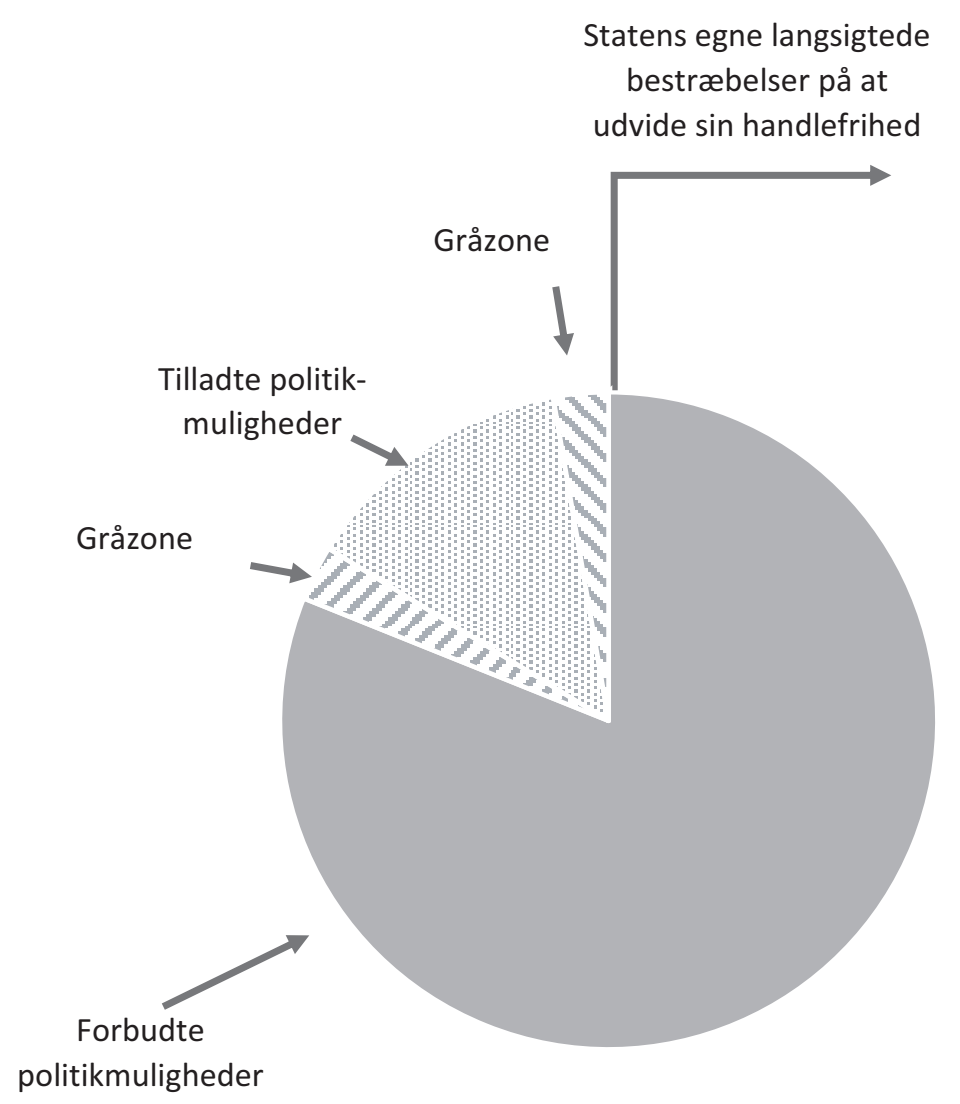

Figur 1. En stats eksterne handlefrihed (tilladte politikmuligheder) i en given situation.

\footnotetext{
${ }^{10}$ Anticiperet reaktion går ud på, at $\mathrm{B}$, som har mindre magt end $\mathrm{A}$, beslutter at afstå fra et bestemt ønske i forhold til A i et forsøg på at undgå konfrontation eller af frygt for, at det ville føre til sanktioner fra A. Begrebet blev oprindelig formuleret af Carl Friedrich (1937, s. 16-18). Se også Bachrach \& Baratz (1970).
} 
Den mindre stat anticiperer en eller flere magtfulde staters reaktioner i forhold til dens forskellige valgmuligheder, men disse reaktioner kan ikke vides med nogen sikkerhed. Den eller de magtfulde må ikke blive utilfredse (goodwill-hensyn), men heller ikke opmuntres til at komme med nye krav. Denne anticipering foretages ofte med en sikkerhedsmargin baseret på 'worst case'-tænkning ("uncertainty avoidance") (Cyert \& March, 1963, s. 118-120; McGowan \& Shapiro, 1973, s. 187). Det er især tilrådeligt, hvis "anger diplomacy" (Hall, 2015, kap. 2) synes involveret fra stormagtens side; irritation og vrede kan føre til uforholdmæssigt store omkostninger for den svage part. Det er ikke let i praksis at skelne mellem 'anger diplomacy' og almindelig afpresning, men for at være på den sikre side er det bedst at lægge lidt ekstra bånd på egen handlefrihed.

Den kendsgerning, at en grænse er utydelig, gør ikke fænomenet - her handlefrihed - mindre virkeligt eller begrebet mindre meningsfuldt. De tre følgende empiriske påstande vil bestrides af de færreste historikere eller IP-forskere:

- De skandinaviske stater havde større handlefrihed end Finland under Den Kolde Krig.

- Europæiske lande opnåede større handlefrihed - nogle mere, andre mindre med ophøret af Den Kolde Krig.

- Mange stater i Asien såvel som i Europa har oplevet en reduceret handlefrihed i forhold til Kina siden starten af det 21. århundrede.

Begrebet handlefrihed er m.a.o. meningsfuldt, og dets intersubjektive brug er mulig, skønt det ikke kan måles præcist. Komparation i store træk er mulig synkront - flere lande på samme tid - eller diakront: én nation på forskellige tidspunkter.

\section{Bilaterale stormagtsdisciplineringer}

Vi vender os nu til de konkrete situationer, hvor grænserne for skandinavisk handlefrihed i udgangspunktet var utydelige, men hvor krisen og den medfølgende stormagtsdisciplinering illuminerede handlefrihedens grænser.

Kinas 'indre anliggender'

I 2009 var den danske statsminister Lars Løkke Rasmussen vært ved et uofficielt møde med Tibets religiøse leder, Dalai Lama. Tidligere havde statsministrene Poul Nyrup Rasmussen (2000) og Anders Fogh Rasmussen (2003) mødtes med ham, ledsaget af moderat kinesisk kritik. Nu antydede Kina imidlertid konsekvenser for dansk eksport og specifikt en kinesisk boykot af COP15, det kommende prestigefyldte FN-topmøde i København om klimaet (Patey, 2019). Imidlertid reddede dansk diplomati situationen gennem et såkaldt 'non-paper' (på engelsk og aldrig autoritativt oversat til dansk, formentlig på grund af dets diplomatiske ømtålelighed). Efter en lang rosende redegørelse for det dansk-kinesiske 
diplomatiske samarbejde siden 1950 kommer følgende formulering (Folketinget, 2009): ${ }^{11}$

Denmark takes very seriously the Chinese opposition to meetings between members of the Danish Government and the Dalai Lama, and has duly noted Chinese views that such meetings are against the core interest of China, and will handle such issue prudently. In this regard, Denmark reaffirms its One-China Policy and its unchanged position that Tibet is an integral part of China. Denmark recognizes China's sovereignty over Tibet and accordingly opposes the independence of Tibet.

Med andre ord bekræftede Danmark ikke kun sin ét-Kina-politik; landet ville endog aktivt "modsætte sig" en hypotetisk tibetansk uafhængighed (som fransk diplomati havde udtrykt det $\mathrm{i}$ en lignende situation året forinden). ${ }^{12} \mathrm{Da}$ denne ydmygende formulering blev kendt, forårsagede den skarp NGO- og mediekritik i Danmark. Blandt de politiske partier var Dansk Folkeparti og Enhedslisten kritiske overfor formuleringen.

I 2010 blev Nobels fredspris tildelt den kinesiske menneskerettighedsaktivist og fængslede dissident Liu Xiaobo. Eftersom pristildelingen besluttes af norske (dog typisk forhenværende) toppolitikere, ${ }^{13}$ fortolkede den kinesiske ledelse det som en ideologisk fjendtlig handling, som blandede sig i indre kinesiske anliggender (Sverdrup-Thygeson, 2018). Norge var faktisk blevet advaret på forhånd om de negative konsekvenser, en sådan tildeling ville have for de kinesiske-norske relationer, og Norges daværende udenrigsminister, Jonas Gahr Støre, forsøgte at afværge kommitéens valg. ${ }^{14}$ Resultatet blev en nedfrysning af de bilaterale relationer indtil slutningen af 2016, en konflikt uden fortilfælde i Kinas nyere forhold til noget OECD-land. Skønt de økonomiske konsekvenser blev mindre alvorlige end forventet, var afskæringen af den fortløbende dialog med den kinesiske stormagt højst problematisk for varetagelsen af Norges globale interesser (især som ikke-EU land). Norsk diplomati forsøgte at løse sagen med et non-paper inspireret af den danske Dalai Lama-model, men planerne lækkede og blev mødt med et kor af hjemlig fordømmelse. Til sidst blev knuden imidlertid løst (december 2016) efter top-hemmelige forhandlinger gennem en fælles erklæring fra de to regeringer (Sverdrup-Thygeson, 2018, s. 82-84). Ifølge dokumentet - med "uld i mund" - vil Norge "ikke støtte handlinger der underminerer [Kinas kerneinteresser og hovedbekymringer]." Der var ingen udtrykkelig

\footnotetext{
${ }^{11}$ På Udenrigsministeriets hjemmeside er teksten nedtaget. I ambassadør Ulbæks (2015, s. 222) omtale nævnes den kontroversielle sætning ikke.

${ }^{12}$ Da Dalai Lama i 2008 var blevet modtaget i Frankrig (ligeledes 'privat'), havde Frankrig måttet reparere forholdet til Kina med formuleringer med en slående lighed med de danske. Den sidste sætning lød: "... France objects to all support for Tibet's independence in any form whatsoever" (New York Times, 2009).

${ }^{13}$ Stortingets Nobel-kommité udpeges af Stortinget, men rummer ikke nuværende regerings- eller stortingsmedlemmer. Typisk består den af fhv. toppolitikere, i store træk vægtet efter partifarve.

${ }^{14}$ Se BBC (2015), der henviser til Lundestad (2015).
} 
undskyldning. Men Norge har siden hen været omhyggelig med at leve op til ånden i erklæringen. ${ }^{15}$ I øvrigt har statsminister Solberg og endog det norske kongepar, i spidsen for en erhvervsdelegation, besøgt Kina (Bekkevold, 2021).

Svensk-kinesiske relationer har lidt skade siden 2015, da Hongkong-forlæggeren Gui Minhai, en svensk statsborger, blev kidnappet af kinesiske myndigheder under en ferie i Thailand og derefter fængslet. Gui var kendt for at publicere kritiske bøger om den kinesiske ledelse. Skønt han tilstod ulovlige forretningsaktiviteter på kinesisk stats-TV, har Sverige støttet af EU fortsat med at forlange ham løsladt. I 2019 tildelte den svenske kulturminister Gui Minhai, i hans fravær, en pris på vegne af svenske PEN. Da den kinesiske ambassadør truede med modforholdsregler, erklærede statsminister Stefan Löfven, at "vi har ikke til hensigt at vige for trusler som disse. Nogen sinde. Vi har ytringsfrihed i Sverige, og det er det, der gælder her. Punktum" (SVT, 2019). Ambassaden svarede på sin hjemmeside, at "den alvorlige fejl fra svensk side [ministerens rolle i prisuddelingen] medfører uundgåeligt alvorlige vanskeligheder for opretholdelsen af venskabelig udveksling og samarbejde mellem Kina og Sverige." Og Kina aflyste planlagte handelsdelegationers besøg i Sverige. I februar 2020 blev Gui Minhai idømt 10 års fængsel for illegal underrettelsesvirksomhed; ifølge retten havde han fået sit kinesiske statsborgerskab tilbage i 2018 (og derved mistet sit svenske). Endvidere havde Gui erkendt sig skyldig og ville ikke appellere dommen. Sverige kræver fortsat hans løsladelse, skønt han tidligere har erklæret på kinesisk TV, at Sverige har "snydt" ham og at han derfor frabad sig yderligere svensk indblanding i sin sag.

\section{I den russiske 'fryser'}

Mens Danmark forberedte et russisk statsbesøg i København i oktober 2002, tillod myndighederne afholdelse af en tjetjensk verdenskongress $i$ byen, mindre end en uge efter at næsten 1.000 teatergæster var blevet taget som gidsler af tjetjenere $i$ Moskva (Mellander \& Mouritzen, 2016, s. 452-454). Danske myndigheder nægtede at udlevere en af talerne, general Ahmed Zakajev, russernes hovedmistænkte for gidseltagningen, til Rusland. Russerne svarede med at annullere statsbesøget, bl.a. med henvisning til, at det ville indebære en alvorlig risiko for terroristangreb mod præsident Putin. Ifølge statsminister Fogh Rasmussen var Danmark ikke længere underdanig i forhold til stormagter (hvorved Rusland blev sammenlignet med tidligere tiders Tyskland). Det er også sandsynligt, at statsministerens udtalelse om, at episoden illustrerede dansk forsamlingsfrihed, ytringsfrihed og et stærkt retsvæsen (modsat Rusland, formodentlig), ${ }^{16}$ fornærmede den russiske side og dermed førte til ca. syv års nedfrosne relationer.

I 2008, da de dansk-russiske forbindelser var ved at tø op, sammenlignede den svenske udenrigsminister, Carl Bildt, Ruslands intervention i Georgien med

\footnotetext{
${ }^{15}$ Se f.eks. et polemisk indlæg af Hustad (2020).

${ }^{16}$ Fyllandsposten 12 . november 2002.
} 
Nazi-Tysklands underminering af Tjekkoslovakiet 1938-39. Rusland svarede med at lægge Sverige, og især Carl Bildt, på is - helt frem til i dag. Andre indbyrdes problemer har fastholdt denne tilstand, f.eks. negative svenske udtalelser om det russiske Duma-valg 2012 eller dommen mod oppositionspolitikeren Navalny ${ }^{17}$ (Mellander \& Mouritzen, 2016, s. 455-456). Mindre forbedringer i de senere år kan dog noteres.

De gode norsk-russiske relationer blev forringet fra omkring 2015. Norge havde tilsluttet sig EU-sanktionerne mod Rusland i kølvandet på Ukraine-konflikten, og det var blevet specificeret, at indrejserestriktionerne mod udvalgte russiske statsborgere også omfattede Svalbard. ${ }^{18}$ Hvorefter en af de udvalgte lod sig fotografere i sneen på Svalbard. Ifølge Svalbard-traktaten af 1925 (SNL, 2020) har indbyggere fra de underskrivende lande, dvs. bl.a. Rusland, fri indrejse til Svalbard med henblik på at bedrive "fredelig virksomhed" (Svalbard er dermed ikke som resten af Norge omfattet af Schengen-reglerne). De norske specifikationer plus efterfølgende indrejsestramninger kunne ifølge russisk opfattelse ikke ses isoleret, men ville skade det indbyrdes forhold mellem de to lande. Siden 2015 er en række irritationsmomenter indtruffet (Moe \& Jensen, 2020). F.eks. protesterede Rusland kraftigt, da Norge var vært ved et møde for NATO-parlamentarikere på Svalbard i maj 2017, eftersom det angiveligt overtrådte den fredelige ånd i Svalbard-traktaten. Rusland modsætter sig generelt en rolle for NATO i Arktis, skønt et lignende NATO-parlamentarikermøde blev afholdt i 2004 uden russiske protester. I 2020 inviterede Ruslands udenrigsminister, Lavrov, sin norske kollega til bilaterale samtaler om Svalbard, hvilket dog blev afslået fra norsk side med henvisning til traktatens multilaterale karakter.

\section{Indien fornærmet}

Efter en periode med øget diplomatisk aktivitet og adskillige aftaler mellem Danmark og Indien blev de bilaterale relationer frosset ned i 2011 (Kaur, 2013; Ulbæk, 2015). Østre Landsret havde stoppet udleveringen af den danske statsborger Niels Holck (alias Kim Davy) til Indien. Niels Holck, der var den hovedmistænkte i en våbennedkastningssag over Purulia (Vestbengalen, Indien) skulle for en indisk domstol og risikerede ifølge landsretten tortur, trods indiske forsikringer om det modsatte (en såkaldt "diplomatisk garanti", IMR, 2018). Den danske statsanklager havde affundet sig med landsrettens afgørelse og ikke appelleret udleveringssagen til Højesteret. Dette skabte vrede i den indiske regering og opinion. Ifølge Kaur (2013) spillede "racisme" i danske medier over for det indiske retssystem også en rolle for den indiske beslutning. Nedfrysningen af de indbyrdes relationer var den første nogen sinde i de diplomatiske forbindelser mellem de to lande og blev beklaget i Danmark, eftersom Indien som en "sovende kæmpe" ses som en partner af strategisk betydning for handel og investeringer (Larson \& Shevchenko, 2014).

\footnotetext{
${ }^{17}$ Der refereres her til Navalnys første dom; den senere formodede forgiftning og nye dom i 2021 er blevet fordømt af en bredere kreds af EU-lande og EU-Kommissionen.

${ }^{18}$ Om russisk Svalbard-politik, se Moe \& Jensen, 2020, s. 514-517.
} 
Efter en gradvis normalisering i løbet af 2018 blev de diplomatiske relationer fuldt normaliseret det følgende år med statsminister Lars Løkke Rasmussens besøg hos Narendra Modi, ledsaget af store delegationer fra dansk industri og landbrug. I 2020 har der været hemmelige sonderinger på topniveau i tilknytning til forhandlinger om et "grønt strategisk partnerskab" mellem de to lande om udlevering af Niels Holck under nærmere angivne betingelser. ${ }^{19}$

\section{Brev fra James Mattis}

I juli 2017 stemte FN's Generalforsamling, med overvældende flertal, for et forbud mod kernevåben (TPNW). ${ }^{20}$ Analogt med forbuddene mod kemiske og biologiske våben var idéen, at traktaten skulle styrke internationale normer mod besiddelse eller anvendelse af denne type våben. Kernevåbenbesiddende lande og alle NATO-lande minus Holland blev væk fra afstemningen. Sverige havde haft en aktiv rolle i traktatforhandlingerne og stemte for, om end med reservationer. Verdensopinionen mod kernevåben blev yderligere styrket, da ICAN ${ }^{21}$ modtog Nobels fredspris i december 2017. Det var forventet, at Sverige med en idealistisk og antinuklear profil ville underskrive og ratificere traktaten uden de store betænkeligheder.

Imidlertid havde den svenske forsvarsminister, Peter Hultqvist, i september samme år modtaget et brev fra sin amerikanske kollega, James Mattis, som truede med, at Sveriges "Enhanced Opportunity"-partnerskab med NATO ikke ville blive forlænget, hvis landet underskrev og ratificerede traktaten. Den amerikanske procedure er aldrig at be- eller afkræfte tilstedeværelsen af kernevåben på sine militære enheder. Sverige ville derfor ikke kunne modtage amerikanske forstærkninger i krigstilfælde i overensstemmelse med "Enhanced Opportunity." Dette bragte Sverige i et alvorligt dilemma mellem sin forsvarspolitik og sin idealistiske udenrigspolitik. Regeringen blev internt splittet.

Eftersom der var stærk folkelig opbakning til traktaten, blev sagen udskudt til efter valget i september 2018 ved hjælp af en grundig regeringsudredning (Utrikesdepartementet, 2019). I juni 2019 erklærede Wallström - baseret på udredningens konklusion - at Sverige ville afstå fra at underskrive eller ratificere traktaten "på nuværende tidspunkt" (https://www.icanw.org/sweden). Sverige havde med andre ord revideret sin tidligere position på grund af brevet fra Mattis kombineret med det presserende behov for forstærkninger ved en militær konflikt i Østersøområdet. Sverige havde ikke handlefrihed til at opfylde sin idealistiske udenrigspolitiske ambition.

\footnotetext{
${ }^{19}$ Bl.a. skulle Holck i så fald varetægtsfængsles i et såkaldt 'safehouse' i Vestbengalen under retssagen. Se Vibjerg \& Maressa (2020).

${ }^{20}$ Treaty for the Prohibition of Nuclear Weapons.

${ }^{21}$ International Campaign for the Abolishment of Nuclear Weapons, en NGO, der arbejder for afskaffelsen af kernevåben, ledes af svenske Beatrice Fihn.
} 
Et 'absurd' forslag

I løbet af foråret og sommeren 2019 forberedtes et officielt statsbesøg af præsident Trump i Danmark efter en invitation af dronning Margrethe. I forlængelse af den amerikanske sikkerhedspolitiske opprioritering af Arktis ytrede Trump i august måned et ønske om køb af Grønland, en del af det danske rigsfællesskab (Restuccia, 2019). Ønsket er tidligere blevet ytret af præsident Truman helt tilbage i 1946 (Salama et al., 2019). Statsminister Mette Frederiksen betegnede under et besøg i Nuuk det fremførte forslag som "absurd", mens landsstyreformand Kim Kielsen var mere diplomatisk. ${ }^{22}$ Det danske ordvalg fik imidlertid præsidenten til omgående at aflyse det planlagte statsbesøg (en aflysning i forhold til en royal invitation var ikke set siden Putin i efteråret 2002, jf. ovenfor). I løbet af de følgende dage lykkedes det dog udenrigsminister Jeppe Kofod at komme i telefonkontakt med sin kollega Mike Pompeo og få glattet ud, ligesom Frederiksen angiveligt senere er kommet på særdeles god fod med præsidenten. Det blev besluttet at gennemføre topmødet ved en senere lejlighed, hvilket dog i praksis ikke viste sig muligt inden for Trumps tid ved magten.

Opsummering: grænseafprøvning og fejlbedømmelser

Situationerne ovenfor er asymmetriske på to måder: For det første er den ene part betydeligt mere magtfuld end den anden. For det andet, paradoksalt nok, er det den svage part, der i udgangspositionen har kritiseret stormagten - ikke omvendt. ${ }^{23}$ I de fleste tilfælde er sidstnævnte asymmetri bragt til ophør i løbet af krisen: Den moraliserende profil blev sænket eller bremset af stormagtens tilsyneladende 'anger diplomacy' (selv i forhold til en allieret magt kan dette spille en rolle; jf. præsident Trumps velkendte irritationspotentiale, som spillede en rolle i 'absurd'-krisen). Bemærk dog, at et par af kriserne endnu er uløste, og handlefrihedens gråzoner derfor stadig intakte.

De væsentlige aspekter ved de analyserede situationer er opsummeret i figur 2. I de kinesiske cases er fællestrækket, at det skandinaviske land har blandet sig i det, der efter kinesisk opfattelse er et 'indre anliggende': Tibets stilling, styrets ideologiske basis eller kinesisk retspleje ( $\mathrm{i}$ forhold til en i udgangspunktet svensk statsborger). De russiske cases har derimod handlet om terrorbekæmpelse, russisk sikkerhedspolitik (interventionen i Georgien) eller folkeret (Svalbard) uden noget ideologisk element. Den indiske case drejer sig om en tidligere terrorsag, men også om en påstået nedladenhed overfor et tredjeverdenslands retskultur og kriminalforsorg. De to amerikanske cases er af vidt forskellig art: Den ene handler om sikkerhedspolitik (kernevåben), den anden om præsidentens personlige nærtagenhed.

\footnotetext{
22 "We are open for business, not for sale" (Economist, 2019).

${ }^{23} \mathrm{Om}$ metoder til måling af småstaters "assertionsniveau", se Mellander \& Mouritzen (2016).
} 
Ingen af de nordiske lande har selvsagt set de bilaterale kriser som ønskværdige, tværtimod. En stormagts udeblivelse fra COP15, aflyste statsbesøg ${ }^{24}$ eller nedfrysning af diplomatiske relationer til en stormagt er alvorlige hændelser. Kunne kriserne være undgået? Gui Minhai-sagen har været uundgåelig for Sverige, da personen er (eller var) svensk statsborger (om end den svenske kulturminister kunne være blevet væk fra prisoverrækkelsen). 'Absurd'-krisen var formentlig nødvendig for at stoppe yderligere spekulationer om salg af Grønland; ordvalget kan diskuteres, men episoder af denne art har været en fast ingrediens i Donald Trumps diplomati.

De resterende sager har derimod ikke været uundgåelige. Konsekvenserne af Nobelprisen til Liu Xiaobo og Dalai Lama-besøget var mere eller mindre forudsigelige. Afvisning af indblanding i 'indre anliggender' har været konsistent siden Folkerepublikkens oprettelse (jf. Gahr Støres forsøg på at komme Nobelkrisen i forkøbet). Ganske vist var der som nævnt 'præcedens' for at modtage Dalai Lama (2000 og 2003) uden voldsom kinesisk kritik, men den kinesiske selvhævdelse var i mellemtiden blevet markant styrket (hvilket selv Frankrig havde erfaret året i forvejen). I de russiske cases anså Moskva sin stormagtsære gået for nær, hvilket heller ikke var uforudsigeligt: at belæres af en Fogh Rasmussen om kvaliteten af sit retssystem i kølvandet på en større gidseltagning kunne umuligt falde i god jord. Det samme gjaldt en Carl Bildts belæring om en parallel mellem Nazi-Tysklands og Ruslands ageren (reaktionen skyldtes formentlig bl.a. Ruslands historiske rolle i bekæmpelsen af nazismen). Og Norges kontroversielle folkeretslige udlægning af Svalbard-traktaten var som at invitere til juridisk disput om en detalje. ${ }^{25}$ Niels Holck-sagen kunne være undgået ved en (omkostningsfri) appel til Højesteret. Det samme gælder det ydmygende svenske tilbagetog i sagen om kernevåbenforbuddet: Princippet om 'neither confirm, nor deny' var velkendt; Pentagon vil for enhver pris undgå præcedens $i$ andre dele af verden.

Men hvorfor fremturede skandinaverne så? Uden adgang til konfidentielle samtaler bliver svarene kun kvalificerede gæt. Specielt i de russiske sager har man nok anticiperet mindre bump på vejen, men næppe så langstrakte diplomatiske isoleringer; den involverede russiske prestige er blevet undervurderet. For Fogh Rasmussen passede Ruslands-krisen som fod i hose til hans lancering af Danmark som ikkesmåstat (Mellander \& Mouritzen, 2016); Danmark skulle ikke længere være ydmyg overfor større magter. Nobel-sagen har formentlig været drevet af værdipolitisk overbevisning. Det gælder også kernevåbenforbuddet: den hjemlige opinion, styrket af ICAN-publiciteten i forbindelse med tildelingen af Nobels fredspris. I Niels Holck-sagen spillede også forskningsinstitutioner og NGO'er ${ }^{26}$ en vis rolle. Det er

\footnotetext{
${ }^{24}$ Om statsbesøgs betydning for generel status, se Haugevik (2015).

${ }_{25}$ "... norske myndigheter har selv skapt et potensielt problem som de strengt tatt ikke hadde trengt" (Moe \& Jensen, 2020, s. 517).

${ }^{26}$ Institut for Menneskerettigheder (IMR) og forsknings- og rehabiliteringsorganisationen Dignity, Dansk Institut mod Tortur.
} 
netop disse motiver, mere eller mindre internaliserede af de skandinaviske beslutningstagere, der har skabt de beskrevne dilemmaer. I denne forbindelse kan det ikke udelukkes, at vanetænkning (kognitiv inerti, e.g. Welch, 2005) fra unipolariteten i de favorable 1990 'ere og tidlige 2000 'ere kan have spillet en rolle hos politikerne: at de som 'norm entrepreneurs' blev vænnet til at evaluere andre lande, f.eks. i forbindelse med konditionalitet i bistandshjælpen (god vestlig regeringsførelse) eller i EU's udvidelsesproces (af formen: 'lav om på jeres samfund eller bliv udenfor'). Vane kan også have spillet ind vedr. Dalai Lama: tidligere statsministre plejede jo at modtage ham 'privat', så hvorfor skulle Lars Løkke Rasmussen ikke kunne gøre det samme?

Et par af sagerne har formentlig handlet om (dristig) grænseafprøvning. Generelt har ingen sager dog ført til forbedringer på de pågældende områder; højst er man vendt tilbage til en status quo-situation. Men selv i de tilfælde har der været tale om en langsigtet disciplinering af skandinaverne; ingen af dem ønsker en gentagelse, alt andet lige.

\begin{tabular}{|c|c|c|c|c|}
\hline Bilateral sag & Overtrædelse & Nordisk motivlårsag & Sanktion & Evt. løsning \\
\hline \multicolumn{5}{|l|}{ Ift. Kina } \\
\hline Dalai Lama (DK) & 'Indre anliggende' & Opinion, vane & COP15 trussel & Verbalnote \\
\hline Nobelpris (N) & 'Indre anliggende' & Menneskerettigheder & Nedfrysning & Fælles erklæring \\
\hline Gui Minhai (S) & 'Indre anliggende' & Menneskerettigheder & Eksport & Ej løst \\
\hline \multicolumn{5}{|l|}{ Ift. Rusland } \\
\hline Zakajev (DK) & $\begin{array}{l}\text { Terrorrisiko, } \\
\text { disrespekt }\end{array}$ & $\begin{array}{l}\text { Prøve grænser } \\
\text { (AFR: DK ej småstat) }\end{array}$ & Nedfrysning & B1.a. NS1 \\
\hline Carl Bildt (S) & Nazikort, disrespekt & Prøve grænser? & Nedfrysning & Ej løst \\
\hline Svalbard (N) & Folkeret, disrespekt & Prøve grænser? & Forsuring & Ej løst \\
\hline \multicolumn{5}{|l|}{ Ift. Inden } \\
\hline Niels Holck (DK) & $\begin{array}{l}\text { Ej udleveret } \\
\text { terrorist, 'racisme' }\end{array}$ & Frygt for tortur & Nedfrysning & Mulig udlevering \\
\hline \multicolumn{5}{|l|}{ Ift. USA } \\
\hline Kernevåbenforbud (S) & Militær SOP ${ }^{\star}$ & Opinion, idealisme & Ej forstærkning & Ej ratifikation \\
\hline Grønlandskøb? (DK) & $\begin{array}{l}\text { Personlig } \\
\text { fornærmelse }\end{array}$ & Spontan udtalelse & Aflyst statsbesøg & Telefonsamtaler \\
\hline
\end{tabular}

Figur 2. Stormagters 'disciplineringer' af skandinaver i bilateralt diplomati (21. århundrede).

*Standard operating procedure: 'neither confirm, nor reject.'

Det skal bemærkes, at Finland, med sin noget tilbageholdende og pragmatiske udenrigspolitiske kurs, har undgået de nedfrysninger, dets skandinaviske naboer har været udsat for. Skønt Finland med sit bibeholdte territorialforsvar har gjort sig mindre afhængig af militære forstærkninger end Sverige, stemte Finland ikke for TPNW i FN's Generalforsamling. Den teoretiske mulighed for forstærkninger er 
et diplomatisk kort på hånden i forhold til Rusland, som Finland ikke har villet smide væk.

\section{Bastionsforsvar kontra goodwill: et dilemma}

Indrømmelser til en stormagt gives ikke drypvis, men er indbyrdes forpligtende. Det betyder, at en beskeden og tilsyneladende harmløs indrømmelse kan føre til mere vidtgående fremtidige indrømmelser, fordi den opmuntrer til yderligere krav. Den skaber forventninger om mere. Den forærer stormagten en overtalelsesplatform af formen: "I har tidligere erklæret jeres venskab overfor os; nu da vi virkelig har brug for det, må I vise det i praktiske gerninger." Den svagere parts taktik bør derfor være at undgå den første, tilsyneladende harmløse, indrømmelse.

Dette gøres bedst ved at opbygge en troværdighed omkring et sæt relevante principper (bastioner). ${ }^{27}$ Hver bastion (Mouritzen, 2017, s. 78-80) består af et sæt indbyrdes forpligtende (potentielle) indrømmelser. Et værdipolitisk princip kan f.eks. være menneskerettigheder i bred forstand eller ytringsfrihed: "Ytringsfrihed er en uvurderlig egenskab ved demokrati, som vi vil forsvare for enhver pris." Dette kan formuleres i bilateral samtale med stormagten eller offentligt. Begge dele er bastionsforsvar. Offentligt har det selvsagt størst troværdighed, fordi regeringens evt. senere svigt vil blive noteret af en større kreds, national såvel som international (selvbinding, f.eks. Hall 2015: 78). Ytringsfrihed kan hævdes som et globalt princip eller, i pressede situationer, begrænset til ens eget land (f.eks. Sverige under 2. Verdenskrig eller Danmark i slut-1930'erne).

Undertiden er indrømmelser imidlertid nødvendige for at sikre et minimum af goodwill hos en stormagt som i de bilaterale kriser ovenfor. Dette er 'bastionspenetration', hvis indrømmelserne udgør en del af en bestemt bastion. For at redde bastionen fra yderligere penetration eller sammenstyrtning er det nødvendigt at skjule, underspille eller omfortolke penetrationen. Dette handler om bastionens troværdighed. Dette sikres af vagheden f.eks. i den norsk-kinesiske fælleserklæring (Nobelsagen) eller i den diskrete svenske retræte vedrørende kernevåbenforbuddet. Den danske verbalnote, derimod, er udtryk for en regulær sammenstyrtning af bastionen om Tibet-solidaritet.

Den delikate balance går ud på at sikre et minimum af stormagtsgoodwill uden unødigt at opmuntre stormagten til yderligere krav og dermed risikere bastionspenetration. I tilfælde af sammenstyrtning af en bastion må en ny og mindre ambitiøs bastion formuleres og gøres troværdig. Omvendt kan det være realistisk, hvis magtforholdene og dermed handlefriheden udvikler sig favorabelt, at etablere en mere fremskudt, ambitiøs bastion - men stadig med troværdigheden i behold. Ifølge Nikolaj Petersen kræver det større kompetence hos beslutningstagerne at fornemme,

\footnotetext{
${ }^{27}$ Hall (2015, s. 169) taler om at signalere "the issue at stake as one of principle" (uden dog at anvende bastionsmetaforen).
} 
hvornår det er tid at forsøge at udvide handlerummet, end at indskrænke eller bibeholde det (Petersen, 2006).

\section{Læring om handlefrihed: forskellige metoder}

De studerede situationer handler om at lære på den risikable måde, dvs. ved faktisk at udføre kontroversielle handlinger for at identificere handlefrihedens grænser. De er en art eksperimenter i naturlig størrelse. Sådanne eksperimenter kan imidlertid udføres mindre risikabelt. Dels kan man udføre et eksperiment i mindre skala (opsende en 'prøveballon'). Dels kan man gå komparativt til værks: kigge til siden (hvad gør andre sammenlignelige lande - paralleladfærd), kigge bagud (hvad gjorde vi sidst - fortidens skygge), eller kigge frem (ekstrapolere - fremtidens skygge). Metoderne og deres begrænsninger kan beskrives således:

- At opsende en 'prøveballon'. Beslutningstagerne tester deres handlefrihed i et mindre eksperiment. Den relevante stormagts respons analyseres i en beskeden sag med begrænset offentlighed; der er meget lidt prestige på spil, og ingen risikerer at tabe ansigt. I et asymmetrisk bilateralt forhold kan der opsendes prøveballoner fra både den stærke og den svage side. Sidstnævnte vil dog være mest tilbøjelig til det, da den har mere at miste ved en evt. konflikt. Den stærke side vil formentlig være mere utålmodig og foretrække at prøve grænser, dvs. eksperimentere i naturlig størrelse. En prøveballon er sandsynligvis den bedste metode til at teste handlefrihed, men det er langtfra sikkert, at et troværdigt 'ballon-emne' er for hånden i situationen.

Som eksempel kan nævnes Stockholm-planen fra juni 1938 (Suomi, 2015; Wahlbäck, 1964), som var en svensk-finsk prøveballon med henblik på et militært forsvar af det demilitariserede Åland (som tilhører Finland, men med selvstyre og svensksproget befolkning). Med øgruppens strategiske beliggenhed tæt på Stockholm ville enhver tredjeparts besættelse af den (i praksis Sovjetunionen eller Tyskland) medføre en 'pistol i ryggen' på Sverige (i mindre grad Finland). Prøveballonen blev imidlertid punkteret, primært af sovjetisk mistro. ${ }^{28}$ Befæstningen blev udskudt og aldrig ført ud i livet.

- Paralleladfcerd ("parallel action"). Denne metode (Mouritzen, 1997; Mouritzen \& Wivel, 2005, s. 190-193; Røren \& Wivel, upubl.) går ud på at lære af 'lignende' landes handlefrihed i forhold til en tilsvarende udfordring. Typisk ville det være stater i samme uformelle gruppering (f.eks. Visegrad-landene eller de nordiske lande). Bastioner forsvares synkront og flyttes frem samtidig, så man støtter hinanden. Svagheden ved 'parallel action' er, at selv nabolande af samme størrelse og med

\footnotetext{
${ }^{28}$ I sovjetisk optik var en befæstning med finske tropper et led i en finsk-tysk sammensværgelse med henblik på at sikre tysk hegemoni i Østersøen (Suomi, 2015).
} 
samme værdisystem kan stå overfor forskellige udgaver af den samme udfordring, hvilket gør paralleladfærd urealistisk.

Norge og Danmark praktiserede paralleladfærd i form af en fælles 'lav profil' i NATO under Den Kolde Krig (ingen fremmede baser eller kernevåben på deres territorium i fredstid eller NATO-øvelser tæt på Warszawa-pagt territorium Kolahalvøen eller Bornholms farvand). De to mindre allierede kunne inspirere og støtte hinandens profil, både internt i NATO og overfor Sovjetunionen. Hvis Norge f.eks. havde handlefrihed i alliancen til at modsætte sig amerikansk flystationering i fredstid (1952), måtte Danmark også have det (Beukel, 1974, s. 41-46). I et internt dansk notat hedder det, at der ikke må være nuancer mellem "broderlandenes" holdninger, og at evt. ændringer i basepolitikken må ske samtidig (Beukel, 1974, s. 42).

- Historiens lare (the "shadow of the past"). I stedet for at kigge over skulderen som i paralleladfærd kan beslutningstagere kigge i 'bakspejlet' og reflektere over statens egen handlefrihed i en tilsvarende historisk sag og spørge: "Hvad kunne vi tillade os sidste gang?" Der er både en positiv og negativ udgave af dette. Den positive går ud på at gentage, hvad der er blevet opfattet som en success; den negative går ud på at gøre det modsatte af en perciperet fiasko (f.eks. May, 1973; Jervis, 1976; Reiter, 2006). Svagheden ved metoden er, at to situationer i et lands udenrigspolitiske historie sjældent ligner hinanden så meget, at der foreligger eksakt samme handlefrihed. Risikoen er så, at en uhensigtsmæssig lære bliver uddraget, eller en lektie bliver overindlært.

I Tysklands-diplomatiet efter det traumatiske nederlag til Preussen/Østrig i 1864 indtog danske beslutningstagere de næste knap 100 år således en (over)forsigtig holdning, evt. ligge død, hvor man ikke udnyttede sin objektive handlefrihed fuldt ud (Branner, 1972, s. 266-267, Lidegaard, 2003, s. 160-162).

- Fremtidens skygge (the "shadow of the future"). I stedet for fortiden handler det her om fremtiden. Beslutningstagerne forsøger at vurdere landets handlefrihed i lys af trendfremskrivninger. Man vurderer den relevante (lokale) magtbalance, ud fra hvad der kan aflæses globalt eller i 'krystalkuglen'. Der er altid fordele ved at være 'first mover', hvis man er heldig, men overoptimisme i form af ønsketænkning er selvsagt også en risiko. Fremtidens skygge kan være lige så vildledende som fortidens. ${ }^{29}$

De europæiske modstandsbevægelser og eksilregeringer kunne fra december 1941 være rimeligt sikre på, at Tyskland ville ende med at tabe den igangværende

\footnotetext{
${ }^{29}$ Begrebet bruges her noget anderledes end hos Mariager og Wivel (2019, s. 63), hvor skyggen refererer til fremtidige konsekvenser. Dette gør begrebet for bredt, da enhver normal beslutning inddrager fremtidige konsekvenser. Her bruges begrebet kun om en fremtidig tilstand (skimtet $\mathrm{i}$ 'krystalkuglen'), der er afgørende forskellig fra den nuværende tilstand.
} 
krig. Men de kunne ikke vide med nogen sikkerhed, hvornår tidspunktet var modent for lokal modstand. Den mislykkede opstand i Warszawa i august 1944 (Taylor, 1998) er et eksempel herpå.

\section{Samspil med den hjemlige handlefrihed}

At overspille sin hånd er naturligvis uheldigt. Men også det modsatte er en fejl: at beslutningstagerne er overforsigtige og sætter landets almindelige status (e.g. Larson et al., 2014; Wohlforth et al., 2018) i verden overstyr, så det i værste fald bliver betragtet som satellitstat. Udover at opmuntre stormagten unødigt - jf. behovet for bastioner - kan indrømmelser også udsætte dem for hjemlig kritik. Ligesom eksternt forsøger beslutningstagere på den hjemlige arena at anticipere, hvorvidt og hvordan opinionen eller bestemte interessegrupper vil reagere på forskellige udenrigspolitiske beslutninger. Dog er gråzonen omkring den hjemlige handlefrihed mere beskeden end omkring den eksterne, fordi der er tale om et mere velkendt miljø.

I det norske Nobel-case så vi skarp mediekritik af regeringen, da rygter om et non-paper kom i omløb. I andre tilfælde var der kun mobiliseret en svag opinion, og $\mathrm{i}$ atter andre kom opinionen for sent til at spille en rolle (det er netop et af formålene med regeringernes udstrakte brug af hemmeligholdelse eller diskretion). Verbalnoten (Dalai Lama) var et eksempel på det. I den svenske kernevåbensag så vi, hvordan regeringen trak tiden ud ved hjælp af en grundig udredning, som først blev offentliggjort efter rigsdagsvalget.

Ifølge Hanrieders formulering (1967) bør beslutningstagerne identificere fællesmængden mellem "compatibility" og "consensus". En given politik skal både have hjemlig konsensus og være forenelig (kompatibel) med de relevante dele af omverden (ekstern handlefrihed). Der skal m.a.o. både være eksternt og internt handlerum for den (Putnam, 1988; Moravscik, 1999). I nærværende sammenhæng er der på den eksterne arena differentieret mellem at sikre goodwill og bedrive bastionsforsvar; de to hensyn trækker som oftest i hver sin retning og skaber derved et svært dilemma for beslutningstagerne.

Fra et IP-realistisk synspunkt har den eksterne handlefrihed primat (Lobell, Ripsman \& Taliaferro, 2009, 2016, s. 52-56 og 94-95). Dvs. staten 'tillader' debat i de mindre essentielle emner, men bruger instrumenter som hemmeligholdelse, manipulation eller intetsigende erklæringer, hvis der er den mindste risiko for uacceptable udfald. Mariager \& Wivel (2019, s. 58-61) opererer f.eks. med en "økonomisk" informationspraksis fra regeringen i forhold til opposition og medier.

Den hjemlige opinion har i flere tilfælde spillet en rolle før krisen, men sættes ofte skakmat af regeringerne, så snart det ydre pres indfinder sig. Tilbage bliver at sikre den delikate balance mellem de to eksterne hensyn: goodwill og bastionsforsvar. 


\section{Objektive, omend utydelige, grænser og en kritisk platform}

Bilateralt diplomati har af forskellige grunde fået stigende betydning i dagens multipolære verden. Dette har været ugunstigt for små og mellemstore lande, som foretrækker multilateralt diplomati, hvor afhængighedsspredning er muligt. Vi har her analyseret adskillige situationer, hvor selvbevidste skandinaviske lande - ikke det pragmatiske Finland - er blevet 'disciplineret' bilateralt af stormagter (Rusland, Kina, Indien eller USA). Sammenlignet med de første 10-15 år efter Den Kolde Krig med amerikansk hegemoni og EU's normative magt har de nordiske lande måttet erfare en indsnævring af deres handlefrihed. Det er ikke længere muligt, uden betydelige omkostninger, at kritisere stormagternes interne forhold eller deres udenrigspolitik baseret på universelle værdier. Sandt nok bruger de skandinaviske lande ofte forskellige offensive strategier i kraft af at have udviklet forskellige repertoirer, men kommer de under bilateralt pres, er reaktionerne forbløffende ens. Så er det 'back to basics' og delikate dilemmaer.

Stater har to dilemmaer i udenrigspolitikken, hvis de er under pres. For det første skal de finde et kompromis mellem bastionsforsvar og goodwill-hensyn til den pressende stormagt. For det andet skal dette kompromis afvejes i forhold til en intern opinion, hvis en sådan er mobiliseret i situationen.

Det var i udgangspunktet vanskeligt for beslutningstagerne i de analyserede situationer at identificere de præcise grænser for handlefriheden. To af konflikterne var nødvendige, mens resten formentlig havde kunnet undgås. Men samtidig kan de anskues som måder at prøve grænser af på. Netop fordi enhver vurdering af handlefrihed hviler på 'anticiperet reaktion' (formodninger om stormagtens reaktionsmønster), opstår betydelige gråzoner, der først afklares i en evt. konflikt.

For ikke at blive yderligere presset kan det være påkrævet med mellemrum at forsvare eksisterende bastioner indædt eller endog flytte bastionerne frem. I stedet for disse eksperimenter i naturlig størrelse - 'learning by doing' - er det dog også muligt at vurdere handlefriheden ved mere subtile metoder: at opsende en prøveballon, lære af lignende lande i tilsvarende situationer (paralleladfærd), reflektere over statens egen handlefrihed i en tilsvarende historisk situation ('fortidens skygge') eller basere sig på trendfremskrivninger ('fremtidens skygge'). Hver af disse metoder har dog også sine svagheder.

Et begreb om objektiv handlefrihed - der imidlertid kun lader sig indkredse ved usikre, intersubjektive metoder - muliggør præskription. I stedet for blotte systematiseringer af stedfundne diskurser bør det i princippet være muligt at give 'gode råd'. Disse vil sjældent handle om, hvilken positiv linje der bør følges i en given situation, men snarere om de ydre grænser for adfærd. Dette eller hint bør undgås. Ifølge sagens natur muliggør en konstatering af handlefriheden også et kritisk potentiale. Har de styrende, i tilfælde af fiasko, overskredet grænserne for statens eksterne handlefrihed, eller skyldes fiaskoen andre årsager? Alternativt kan politikerne kritiseres for ikke at udnytte en eksisterende udenrigspolitisk handlefrihed fuldt ud, dvs. være for frygtsomme og forsigtige. 


\section{Om forfatteren}

Hans Mouritzen, dr.scient.pol., har udviklet teori om flere beslægtede emner: internationale organisationers autonomi, småstatspolitik og dens rumlige forudsætninger, hvordan ekstern fare påvirker internt sammenhold, og hvordan historisk erindring indvirker på nutidens udenrigspolitiske beslutninger ('fortidens skygge').

\section{Litteratur}

Bachrach, P. \& Baratz, M. (1970). Power and poverty. Oxford University Press.

BBC. (2015, 17. september). Nobel secretary regrets Obama peace prize. BBC. https://www.bbc.com/news/ world-europe-34277960

Bekkevold, J. I. (2021). Norges relasjon med Kina i 70 år: Småstatsidealisme og realisme i møte med en stormakt. Internasjonal Politikk, 79(1), 65-89.

Beukel, E. (1974). Socialdemokratiet og stationeringsproblemet 1952-53. En sikkerhedspolitisk beslutning. Odense University Press.

Björkdahl, A. (2007), Swedish norm entrepreneurship in the UN. International Peacekeeping, 14(4), 538-552.

Boulding, K. (1962). Conflict and defense. Harper \& Brothers.

Branner, H. (1972). Småstat mellem stormagter. Beslutningen om mineudlcegning august 1914. Munksgaard.

Cyert, R. \& March, J. (1963). A behavioral theory of the firm. Prentice-Hall.

Dunér, B. (1979). Autonomy: What do we mean, and what do we know? I K. Goldmann \& G. Sjöstedt (Red.), Power, capabilities, interdependence (s. 193-208). Sage.

Economist. (2019, 16. august). A polarising president: Donald Trump wants to buy Greenland. The Economist. https:/www.economist.com/europe/2019/08/16/a-polarising-president-donald-trump-wants-to-buygreenland

Fiammenghi, D. (2019). "Anarchy is what states make of it": True in a trivial sense; otherwise, wrong. International Politics, 56(1), 17-32.

Folketinget. (2009). https://www.ft.dk/samling/20091/almdel/UPN/bilag/24/index.htm

Friedrich, C. J. (1937). Constitutional government and politics. Harper.

Hall, T. (2015). Emotional diplomacy. Official emotion on the international stage. Cornell University Press.

Handel, M. (2006). Weak states in the international system. I C. Ingebritsen, I. Neumann, S. Gstöhl \& J. Beyer (Red.), Small states in international relations (s. 149-193). University of Washington Press.

Hanrieder, W. (1967). Compatibility and consensus: A proposal for the conceptual linkage of external and internal dimensions of foreign policy. American Political Science Review, 61(4), 971-982.

Haugevik, K. (2015). Status, small states, and significant others: Re-reading Norway's attraction to Britain in the twentieth century. I B. de Carvalho \& I. Neumann (Red.), Small states and status seeking. Norway's quest for higher standing (s. 42-56). Routledge.

Haugevik, K. \& Sending, O. J. (2020). The Nordic balance revisited: Differentiation and the foreign policy repertoires of the Nordic states. Politics and Governance, 8(4), 441-450.

Hustad, J. (2020, 27. november). Norge bøjer nakken. Weekendavisen.

IMR. (2018). Udvisning og Udlevering. Institut for Menneskerettigheder. https://www.ft.dk/samling/20171/ almdel/REU/bilag/338/1918928/index.htm

Ingebritsen, C. (2002). Norm entrepreneurs: Scandinavia's role in world politics. Cooperation and Conflict, 37(1), 11-23.

Jervis, R. (1976). Perception and misperception in international politics. Princeton University Press.

Kaur, R. (2013). In the shadow of Kim Davy: India-Denmark relations in the early $21^{\text {st }}$ century. I Danish Foreign Policy Yearbook 2013 (s. 53-78). DIIS.

Larson, D. et al. (2014). Status and world order. I T. V. Paul, D. Larson \& W. Wohlforth (Red.), Status in world politics (s. 3-33). Cambridge University Press.

Larson, D. \& Shevchenko, A. (2014). Managing rising powers: The role of status concerns. I T. V. Paul, D. Larson \& W. Wohlforth (Red.), Status in world politics (s. 33-58). Cambridge University Press.

Lidegaard, B. (2003). Overleveren, 1914-1945. Dansk Udenrigspolitiks Historie, bd. 4. Gyldendal.

Lobell, S., Ripsman, N. \& Taliaferro, J. (Red.). (2009). Neoclassical realism, the state, and foreign policy. Cambridge University Press. 


\section{Hans Mouritzen}

Lobell, S., Ripsman, N. \& Taliaferro, J. (2016). Neoclassical realist theory of international politics. Oxford University Press.

Lundestad, G. (2015). Fredens sekretcer. 25 år med Nobelprisen. Kagge Forlag.

Mariager, R. \& Wivel, A. (2019). Denmark at war: Great power politics and domestic action space in the cases of Kosovo, Afghanistan and Iraq. I Danish Foreign Policy Review 2019 (s. 48-73). DIIS.

May, E. (1973). "Lessons" of the past. Princeton University Press.

McGowan, P. \& Shapiro, H. (1973). The comparative study of foreign-policy. Sage.

Mellander, M. \& Mouritzen, H. (2016). Learning to assert themselves: Small states in asymmetrical dyads. Two Scandinavian dogs barking at the Russian bear. Cooperation and Conflict, 51(4), 447-67.

Moe, A. \& Jensen, Ø. (2020). Svalbard og havområdene - nye utenrikspolitiske utfordringer for Norge?. Internasjonal Politikk, 78(4), 511-522.

Moravscik, A. (1999). Is something rotten in the state of Denmark? Constructivism and European integration. fournal of European Public Policy, 6(4), 669-681.

Mouritzen, H. (1988). Finlandization. Towards a general theory of adaptive politics. Ashgate.

Mouritzen, H. (1997). Denmark in the post-Cold War era: The salient action spheres. I Danish Foreign Policy Yearbook 1997 (s. 33-52). DIIS.

Mouritzen, H. \& Wivel, A. (2005). Comparative analysis meets theory. I H. Mouritzen \& A. Wivel (Red.), The geopolitics of Euro-Atlantic integration (s. 167-206). Routledge.

Mouritzen, H. (2017). Small states and Finlandisation in the age of Trump. Survival, 59(2), 67-84.

New York Times. (2009, 1 April). French and Chinese leaders meet to end Tibet friction. The New York Times. https://www.nytimes.com/2009/04/02/world/europe/02france.html

Patey, L. (2017). Denmark's China challenge. DIIS Policy Brief. Dansk Institut for Internationale Studier.

Petersen, N. (1979). International power and foreign policy behavior: The formulation of Danish security policy in the 1870-1914 period. I K. Goldmann \& G. Sjöstedt (Red.), Power, capabilities, interdependence. Sage.

Petersen, N. (2006). Efter Muhammed: Handlerummet for den borgerlige udenrigspolitik. Det Krigsvidenskabelige Selskab. https://krigsvidenskab.dk/emne/efter-muhammed-handlerummet-den-borgerligeudenrigspolitik

Putnam, R. (1988). Diplomacy and domestic politics: The logic of two-level games. International Organization, 42(3), 427-460.

Reiter, D. (2006). Learning, realism, and alliances. The weight of the shadow of the past. I C. Ingebritsen, I. Neumann, S. Gstöhl \& J. Beyer (Red.), Small states in international relations (s. 149-193). University of Washington Press.

Restuccia, A. (2019, 18. august). Trump confirms interest in Greenland. The Wall Street fournal. https://www. wsj.com/articles/president-trump-wants-to-take-a-look-at-a-potential-greenland-purchase-advisersays-11566144967

Røren, P. \& Wivel, A. (upubl.) King in the North: Evaluating the status recognition and performance of the Scandinavian countries.

Salama, V., et al. (2019, 16. august). President Trump eyes a new real-estate purchase: Greenland. The Wall Street Fournal. https://www.wsj.com/articles/trump-eyes-a-new-real-estate-purchase-greenland-11565904223

SIPRI. (2020). SIPRI Fact Sheet: Trends in World Military Expenditure. https://www.sipri.org/sites/default/ files/2021-04/fs_2104_milex_0.pdf

SNL. (2020, 29. februar). Svalbardtraktaten. Store Norske Leksikon. https://snl.no/Svalbardtraktaten

Sprout, H. \& Sprout, M. (1957). Environmental factors in the study of international politics. The fournal of Conflict Resolution, 1(4), 309-328.

Suomi, J. (2015). Sovjetunionen - det totala problemet inom Finlands utrikespolitik under 1930-talet. Svenska litteratursälsskapet i Finland.

Sverdrup-Thygeson, B. (2018). The Norway-China relationship: For better, for worse, for richer, for poorer. I B. Sverdrup-Thygeson et al. (Red.), China and Nordic diplomacy (s. 77-100). Routledge.

SVT. (2019, 10. november). Statsminister Stefan Löfven (S): Vi tänker inte falla för den här typen av hot. Sveriges Television. https://www.svt.se/nyheter/inrikes/statsminister-stefan-lofven-s-vi-tanker-inte-falla-forden-har-typen-av-hot

Taylor, A. J. P. (1998). The Second World War and its aftermath. Folio Society.

Ulbæk, S. (2015). Kina og Indien. I R. Mariager (Red.), Danmark og verden efter den kolde krig. 14 ambassadører om dansk udenrigspolitik efter 1989 (s. 213-231). Syddansk Universitetsforlag. 
Utrikesdepartementet. (2019). Utredning av konsekvenserna av ett svenskt tillträde till konventionen om förbud mot kärnvapen.

Vibjerg, T. \& Maressa, J. E. (2020, 7. oktober). Ny model skal bane vej for udlevering af Niels Holck. Fyllandsposten. https://jyllands-posten.dk/indland/ECE12469206/ny-model-skal-bane-vej-for-udleveringaf-niels-holck/

Wahlbäck, K. (1964). Finlandsfrågan i svensk politik 1937-1940. Norstedts Förlag.

Waltz, K. (1979). Theory of international politics. Random House.

Welch, D. (2005). Painful choices. A theory of foreign policy change. Princeton University Press.

Wendt, A. (1992). Anarchy is what states make of it. International Organization, 46(2), 391-425.

Wendt, A. (1999). Social theory of international politics. Cambridge University Press.

Wohlforth, W. C., et al. (2018). Moral authority and status in international relations: Good states and the social dimension of status seeking. Review of International Studies, 44(3), 526-546.

\section{Abstract in English \\ Limits to action space: Scandinavians in bilateral diplomacy}

Bilateral diplomacy is not a Scandinavian favourite sport, but it has become increasingly important in today's world. A number of cases are analysed, in which Scandinavian countries have been "disciplined" bilaterally by great powers (Russia, China, India and the US). Compared to the first 15 years, roughly, after the Cold War, with American unipolarity and EU normative power, the Scandinavians have seen a narrowing of their freedom of manoeuvre (action space). It is no longer possible, without significant costs, to criticise great powers based on universal values. In general, it is crucial for decisionmakers not to overstep their state's freedom of manoeuvre. But on the other hand, they should not be docile and desist from occasionally challenging its limits, also considering their domestic arena. "Bastions" should be credibly construed and defended. The limits of action space are difficult to discern, but trial balloons, parallel action with related countries, or "lessons of the past" could be helpful.

Keywords: freedom of manoeuvre - small states • asymmetrical dyads . bastions 